logos_i_ethos_1_(32)_2012,s. 175-199

\title{
Piotr Karpiński
}

\section{Między nieuchronną skończonością a nieśmiertelnością. Vladimira Jankélévitcha i Józefa Tischnera dwugłos na temat śmierci}

Pogląd, według którego zajmowanie się tematyką śmierci w czasach ponowoczesnych jest rzeczą czczą i zbyteczną, wydaje się prima facie uzasadniony. Powstały na jej temat liczne już opracowania ${ }^{1}$, zarówno teoretyczne, rozważające śmierć samą, jak i praktyczne, swoiste podręczniki ars moriendi, mające człowieka na śmierć przygotować. To, co się dało o śmierci powiedzieć, dawno

ks. Piotr Karpiński (ur. 1977) - dr teologii (praca doktorska pt.: „Teologiczna antropologia kazań ks. Józefa Tischnera”). Absolwent Uniwersytetu Ekonomicznego w Krakowie i Wyższego Seminarium Duchownego w Łowiczu. Wykładowca filozofii nowożytnej i współczesnej w Wyższym Seminarium Duchownym w Łowiczu. Zajmuje się filozofią francuską, fenomenologią, a także współczesnymi prądami teologicznymi. zostało już powiedziane. Opisano wyczerpująco możliwe postawy człowieka wobec śmierci, od jej lekceważenia, poprzez ucieczkę, prowokowanie, aż do prób oswojenia śmierci. Sam temat równie niespecjalnie interesuje współczesnego człowieka. Raczej jest on nastawiony na pozytywne przeżywanie życia, nawet jeśli ocenimy je jako dość powierzchowne i konsumpcyjne. Człowiek dzisiaj żyje według pascalowskiej „rozrywki”, która ma odwracać jego uwagę od zagadnień kłopotliwych, w tym od śmierci.

1 Przykładowa i najbardziej podstawowa literatura na temat filozofii śmierci: Antropologia śmierci. Myśl francuska, wybór i tłum. S. Cichowicz, J. M. Godzimirski, Warszawa 1993; I. Ziemiński, Metafizyka śmierci, Kraków 2010; G. Scherer, Filozofia śmierci od Anaksymandra do Adorno, tłum. W. Szymona, Kraków 2008; D. Karłowicz, Arcyparadoks śmierci. Męczeństwo jako kategoria filozoficzna - pytanie o dowodowa wartość męczeństwa, Warszawa 2007; A. M. di Nola, Tryumf śmierci. Antropologia żałoby, tłum. J. Kornecka i in., Kraków 2006; R. Ferber, Śmierć, [w:] tenże, Podstawowe pojęcia filozoficzne, t. 2, tłum. L. Kusak, A. Węgrzecki, Kraków 2008, s. 187-216;

T. Gadacz, O umiejętności życia, Kraków 2003, s. 63-68, 236-244. 
A jednak problematyka śmierci w naszych czasach powraca. Daje się zauważyć co najmniej dwa obszary, które nie mogą się od niej odseparować. Pierwszym z nich jest obszar refleksji etycznej, a zwłaszcza bioetyki. Takie zagadnienia, jak eutanazja, prawna definicja śmierci, uporczywa terapia, biologistyczna interpretacja życia i wiele innych, siłą rzeczy ewokują problem śmierci². Drugim obszarem jest antropologia, czyli refleksja o człowieku. Czy jest możliwe poznanie i wyjaśnienie ludzkiej egzystencji bez uwzględnienia faktu śmierci? Czy śmierć jest punktem krańcowym, bez większego znaczenia dla życia ludzkiego, czy też świadomość śmierci jakoś naznacza i przekształca samo życie? Nie da się uprawiać odpowiedzialnie antropologii, bez uwzględnienia faktu śmierci³

W niniejszym artykule podejmujemy się refleksji nad śmiercią w tym drugim obszarze, czyli refleksji antropologicznej. Jego przedmiotem jest zrekonstruowanie i skonfrontowanie dwóch antropotanatologii: francuskiego filozofa z kręgu filozofii ducha, Vladimira Jankélévitcha (1903-1985) i Józefa Tischnera (1931-2000), polskiego fenomenologa i twórcy filozofii dramatu. Pomiędzy obydwoma myślicielami istnieją pewne podobieństwa, ale i znaczące różnice. W omawianym tutaj zagadnieniu śmierci jedna rzecz wydaje się doniosła: o ile Tischner szuka chrześcijańskiej filozofii śmierci, o tyle postawa Jankélévitcha jest, najdelikatniej mówiąc, religijnie neutralna. Cóż zatem mogliby powiedzieć sobie nawzajem? Gdzie tkwi bardziej poważne i na serio potraktowanie tematu? A może obydwa punkty widzenia nie są tak całkiem odległe i gdzieś się tajemniczo spotykają?

W refleksji antropologicznej ważne są trzy pytania dotyczące śmierci: po pierwsze, czym jest śmierć sama w sobie, czyli jej opis fenomenologiczny; po drugie, jak świadomość śmierci wpływa na życie samo,

2 Por. J. Kopania, Etyczny wymiar cielesności, Kraków 2003.

Ch. Delsol czyni śmierć punktem wyjściowym swojej filozofii człowieka. Jej zdaniem, to świadomość śmierci wyznacza moment pojawienia się istoty ludzkiej jako takiej: „Pierwszym istotnym pytaniem jest pytanie o śmierć. Twierdzenie, że jest to pytanie podstawowe, nie jest w żadnym razie dowolne. [...] [P]ytanie o śmierć jest charakterystyczną cechą człowieka, oznaczając narodziny odróżnionych od siebie jednostek" (Ch. Delsol, Czym jest człowiek? Kurs antropologii dla niewtajemniczonych, tłum. M. Kowalska, Kraków 2011, s. 17). 
czyli analiza antropologiczna; po trzecie, jakie jest postulowane rozwiązanie problemu śmierci, tak by podjęcie życia w jej horyzoncie stało się w ogóle możliwe. Te trzy pytania wyznaczą przedmiotowy zakres podjętych tu rozważań.

\section{Poszukując sensu i znaczenia śmierci}

Józef Tischner bardzo wcześnie dostrzegł doniosłość problematyki śmierci dla filozofii człowieka i poświęcił jej jeden z pierwszych swoich tekstów, Prolegomena chrześcijańskiej filozofii śmierci ${ }^{4}$, który wszedł do antologii Świat ludzkiej nadziei. Mówiąc o śmierci ludzkiej, należy mieć na uwadze różne jej postaci ${ }^{5}$. O wielorakości śmierci mówił Tischner między innymi w homilii na Mszy św. prymicyjnej, w miejscowości Łapsze Wyżne:

Wiemy o tym dobrze, że są rozmaite śmierci, które nachodzą człowieka. Jedne śmierci przychodzą od zewnątrz, od ciała, ale jest też taka śmierć, która przychodzi od środka, jakby od serca. Tymi śmierciami, które przez ciało przychodzą, zajmują się lekarze. Kapłani zajmują się tą śmiercią, która przychodzi do człowieka od środka, od jego serca ${ }^{6}$.

Z kolei w jednym z kazań w krakowskiej kolegiacie św. Anny padły następujące słowa:

Śmierć przychodzi do człowieka na rozmaitych poziomach jego życia. Jest śmierć ciała, jest śmierć serca, jest śmierć ludzkiego ducha7.

4 J. Tischner, Prolegomena chrześcijańskiej filozofii śmierci, [w:] tenże, Świat ludzkiej nadziei, Kraków 2005, s. 248n.

5 „Musimy uznać pluralizm różnych doświadczeń śmierci” (G. Scherer, Filozofia śmierci. Od Anaksymandra do Adorno, dz. cyt., s. 70).

${ }_{6} \quad$ J. Tischner, Homilia z Mszy św. prymicyjnej w miejscowości Łapsze Wyżne, Archiwum prywatne rodziny Tischnerów, nagranie w Archiwum dźwiękowym Instytutu Myśli Józefa Tischnera w Krakowie, nr NA-162. Dalej podaję numery nagrań.

Tenże, Spotkania u św. Anny, cz. 2, Cykl kazań wygłoszonych w kościele św. Anny w Krakowie $w$ roku 1986, Archiwum prywatne rodziny Tischnerów, nagranie NA-95. 
Tischner dostrzega zatem różne przejawy śmierci, przy czym widzi nie tylko jej formy somatyczne, ale także, niejako metaforycznie, mówi o śmierci ducha. Przejawem tej ostatniej jest życie pozorne:

Człowiek taki budzi się rano, myje się, je śniadanie, idzie do pracy, porusza się, mówi, słychać go, widać, a więc żyje. Ale żyje pozornie. Co to znaczy, żyć pozornie? To znaczy żyć pozorami życia. Ten, kto żyje pozorami życia, nie żyje naprawdę. Umarł".

Samo pojęcie śmierci jest dwuznaczne. Można przez nie rozumieć zarówno zjawisko umierania, jak i śmierć właściwą, czyli zgon ${ }^{9}$. Umieranie jest procesem rozłożonym w czasie i właściwie towarzyszy człowiekowi od chwili narodzin przez całe $\dot{z} y c i e^{10}$. Natomiast zgon jest chwilą, która kończy proces umierania. Różnica nie jest jedynie charakteru czasowego, ale oznacza również inne doświadczenie obu zjawisk. Umieranie nie jest dane człowiekowi wprost, ale jest raczej tłem takich jego przeżyć, jak starzenie się czy choroba, a aktualizuje się w świadomości najczęściej pod wpływem cudzej śmierci. Konanie natomiast jest ukryte jeszcze głębiej, poza umieraniem, stanowiąc jego kres i cel ${ }^{11}$.

Człowiek jest jedyną istotą na świecie, która nie tylko umiera, ale jednocześnie ma świadomość własnej śmierci. Dlatego też tylko człowiek może zająć jakąś postawę wobec własnej śmierci. Jak pisze Tischner:

8 Tamże.

9 Podobnie ujmuje tę kwestię Lévinas. Por. E. Lévinas, Bóg, śmierć i czas, tłum. J. Margański, Kraków 2008, s. 16.

10 „Nawet jeśli śmierć nie jest logicznie konieczna, to wszyscy jej podlegamy. Zgodnie ze starożytnym powiedzeniem, odkąd człowiek się narodził, jest wystarczająco stary, by umrzeć; chwila narodzin to początek umierania” (I. Ziemiński, Metafizyka śmierci, dz. cyt., s. 41). „Każdy z nas jest zatem potencjalnym zmarłym” (L.-V. Thomas, Wprowadzenie do antropotanatologii, [w:] Antropologia śmierci. Myśl francuska, dz. cyt., s. 24). „Życie człowieka toczy się między narodzinami a śmiercią. Grecy nazywali człowieka «śmiertelnikiem». Określenie to wskazuje, że śmierć nie jest po prostu zakończeniem egzystencji, lecz towarzyszy człowiekowi od samego początku” (J. Tischner, Zarys filozofii człowieka dla duszpasterzy i artystów, [w:] tenże, Myślenie w żywiole piękna, Kraków 2004, s. 262).

11 Por. J. Tischner, Prolegomena..., dz. cyt., s. 250. 
„Człowiek może zamykać oczy na własną śmierć, może śmierci wybiegać naprzeciw, może nadawać jej wybrane znaczenie i może wreszcie dokonywać metafizycznego rozstrzygnięcia odnośnie do tego, co go czeka po śmierci”"12. Przy czym nawet w wypadku metafizycznego rozstrzygnięcia o przyjęciu nieśmiertelności nie ma mowy o pewności - stąd śmierć człowieka jest zawsze pełna tragizmu i grozy.

Tischner rozróżnia dwa pojęcia, które służą do opisu fenomenu śmierci: sens i znaczenie. Czym innym jest sens śmierci, a czym innym jej znaczenie. Sens wyłania się niejako $\mathrm{z}$ wnętrza zjawiska śmierci, jest dany podmiotowi jako jej istota. Natomiast znaczenie to jest to, co człowiek próbuje śmierci nadać. Śmierć może bowiem dla człowieka przybierać różne znaczenia, np. znaczenie heroiczne, gdy człowiek umiera za ojczyznę, znaczenie męczeńskie, gdy daje świadectwo prawdzie, czy znaczenie utylitarystyczne, gdy jest ucieczką od kłopotów tego życia. Należy jednak pamiętać, że choć pojęcia sensu i znaczenia śmierci są różne, to jednocześnie są one wewnętrznie powiązane i warunkują się wzajemnie. Fakt, czym śmierć jest, wyznacza zakres możliwych znaczeń śmierci dla człowieka ${ }^{13}$. Przyjrzyjmy się zatem sensowi śmierci, a następnie jej znaczeniom.

Ażeby uchwycić sens śmierci, należy rozważyć dwa kluczowe doświadczenia: śmierć kogoś bliskiego i towarzyszące jej uświadamianie sobie, że ja też mogę umrzeć, czyli możliwość własnej śmierci. Jaka jest fenomenalna istota śmierci, gdy umiera ktoś bliski? W momencie śmierci bliskiego pierwszym doświadczeniem jest świadomość pustki. Tischner przywołuje myśl Bergsona:

Pojęcie pustki rodzi się tutaj, gdy świadomość, opóźniając się w stosunku do samej siebie, pozostaje przywiązana do stanu dawnego, chociaż już inny stan jest obecny. Jest ono porównaniem między tym, co jest, a tym, co mogłoby być lub powinno być ${ }^{14}$.

Tamże, s. 251.

Por. tamże, s. 249.

14 H. Bergson, Ewolucja twórcza, tłum. C. Znaniecki, Warszawa 1959, s. 248. 
Najtrafniej ten stan pustki wyrażają słowa: „jego nie ma”. Tischner zaznacza, że wyrażenie „nie ma” ma nieco inny sens, niż wyrażenie „nie istnieje”. Obok prostego stwierdzenia faktu nieistnienia, ma ono jeszcze jakiś dodatkowy ładunek emocjonalny, jest pełne tragedii, kojarzy się $\mathrm{z}$ rozkładaniem rąk. $\mathrm{Z}$ doświadczenia pustki wyłania się w stronę podmiotu pewien imperatyw:

jego już nie ma, więc i we mnie nie powinno już być wszystkich przeżyć, poprzez które osiągałem go i był mi bliski. Nie wolno oczekiwać spotkań, odpowiedzi na postawione pytania, nie wolno nawet pytań stawiaćc ${ }^{15}$.

W ten sposób doświadczenie pustki przechodzi w zjawisko pustoszenia wnętrza człowieka, który doświadcza śmierci kogoś bliskiego.

Podobnie ma się rzecz w przypadku własnej śmierci. Ujawnia się w niej paradoksalne zjawisko aktywnego pustoszenia. Heidegger mówi o człowieku jako bycie, który nie może uniknąć śmierci: „Śmierć jako kres Dasein jest najbardziej własną, najbardziej bezwzględną, pewną i przy tym nieokreśloną, niemożliwą do uniknięcia możliwością $D a$ sein"16. Człowiek we własnej śmierci staje sam na sam $\mathrm{z}$ nadciągającą aktywnością pustki, przy czym to pustoszenie ma wręcz osobowy charakter: „ono jest ku mnie skierowane, ono mówi: ty” ${ }^{17}$. Pustoszenie przystępuje do zrealizowania swojego zasadniczego celu, jakim jest ogołocenie człowieka z niego samego, a czego wyrazem są zwłoki.

W wyniku doświadczenia pustki rodzą się w człowieku pewne reakcje: trwoga, jako stan emocjonalny, i protest przeciwko śmierci, jako działanie. Trwoga jest czymś innym od strachu. Charakteryzuje

15 J. Tischner, Prolegomena..., dz. cyt., s. 253.

16 M. Heidegger, Sein und Zeit, s. 258, cyt. za: J. Tischner, Prolegomena..., dz. cyt., s. 254. „Umieranie przynależy do Dasein jako niemożliwa do przezwyciężenia (bo nieunikniona), jako najbardziej osobista (bo stawiająca mnie wobec samego siebie w całkowitym ogołoceniu), jako najbardziej irracjonalna (bo zrywająca wszelkie związki z innymi możliwościami) możliwość" (A. de Waelhens, La philosophie de Martin Heidegger, Louvain 1948, s. 144, cyt. za: J. Tischner, Prolegomena..., dz. cyt., s. 254). Por. G. Scherer, Filozofia śmierci. Od Anaksymandra do Adorno, dz. cyt., s. 54.

J. Tischner, Prolegomena..., dz. cyt., s. 255. 
się ona tym, że jej przedmiot jest nieokreślony. O ile strach ma swoją racjonalną przyczynę, np. realnie grożące człowiekowi niebezpieczeństwo, o tyle przedmiot trwogi jest absurdalny. Człowiek w trwodze nie widzi żadnego miejsca, gdzie mógłby się schronić. Bunt $\mathrm{z}$ kolei jest wyrazem męstwa. Ale bunt różni się też od desperacji. Tischner pisze: „W buncie zawarta jest przede wszystkim subtelna i mocna miłość do samego siebie, powiedziałbym nawet: miłość do samego siebie pojęta najuczciwiej, jak tylko może być pojęta i przeżyta w sytuacji, gdy wszystkie wiary zawiodły"18.

Ze śmiercią wiąże się również doświadczenie rozpaczy. Tischner odróżnia tutaj jednak rozpacz jako wewnętrzny nastrój człowieka, ogarniający jego świadomość, od wewnętrznej zgody na rozpacz. Wewnętrzna zgoda na rozpacz dopełnia samą rozpacz w jej funkcji wyniszczającej, jednakże jest nową jakością. Rozpacz związana jest z poczuciem trwogi. Oznacza ona utratę sensu wszystkiego, co człowieka otacza. A skoro nic nie ma sensu, to także nie ma sensu wszelkie chcenie, działanie, granica między dobrem i złem. Rozpacz to totalna inercja człowieka i zerwanie komunii z istnieniem. Jej szczytowym momentem jest wewnętrzna zgoda na rozpacz, która jest aktem rezygnacji z wszelkiej nadziei. Wówczas rozpacz przekształca się w imperatyw samobójstwa. Można powiedzieć, że rozpacz zmusza do czynu: będzie nim albo sprowokowanie śmierci, albo protest wyrażający się ożywieniem nadziei ${ }^{19}$.

Rekapitulując powyższe analizy, można powiedzieć, że podstawowym elementem umierania jest świadomość nadciągającego pustoszenia. Człowiek reaguje na nią całym zespołem nastrojów, które są różne i antagonistyczne wobec siebie: od nastrojów niszczących, jak rozpacz, trwoga, samotność, do nastrojów nastawionych na ocalenie, jak protest i walka, wypływające z nadziei i z pierwotnej miłości do samego sie$b^{20}{ }^{20}$. W ten sposób wytwarza się w człowieku sytuacja wewnętrznej

Tamże, s. 258.

Por. tamże.

20 Por. I. Ziemiński, Metafizyka śmierci, dz. cyt., s. 241. 
walki, ale jej wynik jest z góry nie do rozstrzygnięcia: „Nie wiemy do czego będzie należeć ostatni moment" ${ }^{21}$.

Jaka jest odpowiedź człowieka na zjawisko śmierci? Zdaniem Tischnera, człowiek dokonuje jej racjonalizacji, nadając śmierci rozmaite znaczenia. Nie ma tutaj pełnej dowolności, gdyż zakres możliwych znaczeń wyznacza sens śmierci. Tischner omawia cztery podstawowe znaczenia śmierci: śmierć heroiczną, męczeńską, śmierć jako ucieczkę od świata oraz śmierć sankcyjną.

Śmierć heroiczna to taka, która została poniesiona przy okazji spełniania jakiegoś ważnego czynu. W punkcie wyjścia człowiek decyduje się na zrealizowanie doniosłego czynu, licząc się z możliwością śmierci. Naraża się na śmierć. Gdy śmierć przychodzi, ów czyn, choćby niespełniony do końca, nadaje śmierci szczególną godność.

Nieco inaczej jest ze śmiercią męczeńską. Tutaj sama śmierć jest heroicznym czynem. Przy czym człowiek nie ogranicza się do samej śmierci. Nie o samą śmierć mu chodzi, ale o świadectwo. Tischner pisze: „W śmierci męczeńskiej dwa momenty znaczeniowe są istotne: odsłonięcie treści żywionej wiary i poręczenie wiary i jej treści w obliczu społeczeństwa”22. Męczennik jest przede wszystkim świadkiem, a śmierć jest tutaj pieczęcią jego świadectwa.

Śmierć może być też prostą ucieczką od świata. Jest wówczas realizacją słynnego postulatu Nietzschego: „Umieraj w porę"23. Śmierć taka może mieć kilka wariantów, jak np. odejście po dokonaniu dzieła, gdyż nic już więcej dokonać nie można, albo ucieczka od smutków życia. W każdym razie fenomenalne objawy tego typu śmierci są zawsze te same: odejście, opuszczenie, porzucenie.

${ }^{21} \quad$ J. Tischner, Prolegomena..., dz. cyt., s. 260.

22 Tamże, s. 261.

23 „Wielu umiera za późno, niektórzy umierają zbyt wcześnie. Obco brzmi jeszcze nauka: «umieraj w porę!». Umieraj w porę; tak poucza Zaratustra [...]. Ja wam wskazuję skon dokonywający, skon co dla żywych bodźcem i ślubowaniem się staje. Własną śmiercią umiera dokonywający, umiera zwycięski w otoczeniu ślubujących i nadziei pełnych. Tako umierać powinni się ludzie uczyć [...]. Moją śmierć sławię ja wam, śmierć wolną, która po mnie przyjdzie, ponieważ ja tego chcę" (F. Nietzsche, Tako rzecze Zaratustra, tłum. W. Berent, Kraków 1906, s. 89). Por. I. Ziemiński, Metafizyka śmierci, dz. cyt., s. 111. 
Wreszcie człowiek może śmierci nadać znaczenie sankcyjne. Śmierć tak pojęta jest oskarżeniem i karą dla tych, co przy życiu pozostali, np. za brak miłości albo zrozumienia. Pojawia się ona w niektórych przypadkach samobójstw. Należy dostrzec różnicę pomiędzy tą śmiercią a jej wariantem heroicznym czy męczeńskim. Pojawia się tutaj również odniesienie do drugiego, ale jest ono oskarżeniem, a nie apelem czy świadectwem. A jeśli śmierć ta o czymś świadczy, to tylko o ogromie nieszczęścia tego, kto umiera.

Te wszystkie znaczenia śmierci, które nie są jedynymi możliwymi, mają trzy elementy wspólne. Po pierwsze, każda śmierć ma odniesienie do jakiejś społeczności, nawet najmniejszej. Po drugie, śmierć jest odejściem, ale i pozostaniem zarazem. Przykładowo, świadek odchodzi, ale zostaje w swoim dziele, które będzie kontynuowane przez innych. Po trzecie, sens śmierci jest dla wszystkich wspólny, ale na płaszczyźnie znaczeń ujawnia się indywidualność śmierci. Dlatego też Tischner mówi o „śmierci własnej”. Umieranie człowieka ma wartość indywidualną i jest jedyne w swoim rodzaju.

\section{To, co nieuchronne}

Vladimira Jankélévitcha $\mathrm{z}$ Tischnerem łączy chyba tylko ten fakt, że podobnie do krakowskiego myśliciela filozofował on „bez etykiety”, bez uprzedzeń, przez co trudno go zakwalifikować do jakiegokolwiek systemu czy nurtu filozoficznego. Pochodził z rodziny rosyjskich emigrantów żydowskich, studiował w Paryżu (wielki wpływ i jednocześnie uznanie ze strony Brunschvicga, Simmla i Bergsona), wykładał filozofię w liceach (Caen, Lyon) i na uniwersytetach (Praga, Tuluza, Lille). Nie należał jednak do fenomenologów, egzystencjalistów, czy strukturalistów. W 1951 r. został profesorem filozofii moralnej na paryskiej Sorbonie jako następca Le Senne'a. Zastał jednak na tej uczelni dziwne milczenie wokół Holokaustu i wówczas, z powodów czysto biograficznych, wziął całkowity rozbrat z filozofią niemiecką. Myśl Jankélévitcha, ciągle czekająca na odkrycie, jest synkretyczna i heterogeniczna, to niezwykła mieszanina rosyjskiego mistycyzmu $\mathrm{z}$ francuskim racjonalizmem. 
Przedmiot jego filozofowania dobrze zdradza tytuł głównego dzieła filozoficznego, Le je-ne-sais-quoi et le presque-rien ${ }^{24}$, bo rzeczywiście filozofował „o prawie-niczym”, o nostalgii, niedopełnieniu, o ironii, milczeniu, chwili czy humorze. Ale przez te ulotne doświadczenia obserwował ludzką egzystencję. Swoje poglądy na temat śmierci zawarł w dziele La mort ${ }^{25}$ z 1966 r. To w nim pada kategoryczne zdanie: „Człowiek jest istotą śmiertelną ${ }^{26}$. Według badaczy w zdaniu tym daje się streścić całe dzieło Jankélévitcha, a wszystko inne, co napisał, to zaledwie przypisy i komentarze do tego zdania ${ }^{27}$.

O śmierci można mówić w trzech osobach liczby pojedynczej. Śmierć w trzeciej osobie to śmierć osoby bliżej nieznanej, „śmierć byle kogo, nagły zgon przechodnia z powodu, powiedzmy, zawału"28. To śmierć jako zjawisko demograficzne czy medyczne, przez co jawi się jako coś zupełnie banalnego, niekryjącego w sobie żadnej tajemnicy. Dla lekarza to konieczny element życia, ustanie wymiany energii pomiędzy organizmem a otoczeniem. Dla statystyka lub demografa śmierć nie budzi najmniejszej trwogi, gdyż liczba ludności w ciągu dziejów nieustannie się zwiększa. Śmierć w pierwszej osobie, czyli moja śmierć, to sekret, nic nie możemy o niej powiedzieć. Pozostaje śmierć w drugiej osobie, śmierć kogoś bliskiego, która jest uprzywilejowanym doświadczeniem filozoficznym. Jak mówi Jankélévitch:

Przypomina moją śmierć, a jednak nie jest moją śmiercią, nie jest też bezosobową i anonimową śmiercią, którą interesuje się demografia czy medycyna. Umiera inny człowiek, a więc ja go przeżyję. Mogę zobaczyć, jak umiera. Mogę go ujrzeć martwym. To ktoś inny niż ja, ale jednocześnie jego śmierć dotyka mnie bezpośrednio [...]. Ktoś bliski, umierając, wyręcza mnie w filozofowaniu o śmierci ${ }^{29}$.

$\begin{array}{ll}24 & \text { V. Jankélévitch, Le je-ne-sais-quoi et le presque-rien, Paris } 1957 . \\ 25 & \text { Tenże, La mort, Paris } 1966 . \\ 26 & \text { Tamże, s. } 22 . \\ & \text { Por. M. Kwaterko, Smierć i filozof, [w:] V. Jankélévitch, To, co nieuchronne. Rozmowy }\end{array}$ o śmierci, tłum. M. Kwaterko, Warszawa 2005, s. 11.

28 V. Jankélévitch, To, co nieuchronne, dz. cyt., s. 16.

29 Tamże. 
Swoją koncepcję ludzkiej egzystencji Jankélévitch nazywał dialektyką dwuznacznej skończoności ${ }^{30}$. Człowiek bytuje w czasie, jest niedoskonały i skończony, rozdarty między bytem uniwersalnym a indywidualną egzystencją. Życie ludzkie jest nieprzewidywalnym i nieodwracalnym procesem. Francuski filozof przestrzega jednak przed mitem symetrii, mitem przestrzennego ładu w patrzeniu na człowieka i jego egzystencję. Popadamy w tę pułapkę, kiedy porównujemy śmierć człowieka $\mathrm{z}$ jego narodzinami, a życie traktujemy jako linię łączącą te dwa przeciwstawne bieguny. Jankélévitch stoi na stanowisku, że życie to nie przestrzeń, ale czas, a tego ostatniego nie da się przedstawić przestrzennie. Koncepcja czasu u Jankélévitcha jest identyczna jak u Rosenzweiga - czas nie jest rzeką, lecz wciąż tryskającym źródłem ${ }^{31}$. Pisze Jankélévitch:

Narodziny i śmierć to dwa odrębne momenty: kiedy następuje śmierć, narodziny są już czymś zamierzchłym; kiedy się rodzimy, śmierć jest daleką przyszłością, czymś na razie nie istniejącym. Nie ma symetrii między jednym a drugim $[\ldots]$. Te dwa momenty nie mają ze sobą nic wspólnego. Nie występują łącznie, jednocześnie, nie obejmuje ich żadne wspólne doświadczenie [...]. Przychodząc na świat, zostawiamy nicość za sobą, przyszłość jawi się jako wielka obietnica istnienia; w chwili śmierci zostawiamy za sobą naszą przeszłość i wkraczamy w nicość [...]. Przeszłość i przyszłość nie są ramami otaczającymi teraźniejszość. Żyjemy w wiecznej teraźniejszości ${ }^{32}$.

Ta wypowiedź Jankélévitcha odsłania nam, czym jest według niego sama śmierć. Śmierć jest czymś metafizycznym i irracjonalnym. Jest ostatecznym unicestwieniem osoby, absolutną negatywnością, niebyciem na zawsze: „śmierć jest właśnie śmiercią w tym sensie, że oznacza całkowity zanik, absolutne unicestwienie"33. Na tym polega dramat ludzkiej egzystencji. Śmierć jest najbardziej absurdalnym rodzajem

30 Por. T. Gadacz, Historia filozofii XX wieku. Nurty, t. 1, Kraków 2009, s. 532.

31 Por. V. Jankélévitch, Bergson, Paris 1931, s. 245, cyt. za: T. Gadacz, Historia filozofii XX wieku. Nurty, t. 1, dz. cyt., s. 529.

32 V. Jankélévitch, To, co nieuchronne, dz. cyt., s. 18.

33 Tamże, s. 29. 
komunikatu, nie sposób też nadać mu żadnego sensu. Jest to wydarzenie nagłe, całkowicie zaskakujące:

Narodziny są zupełnie innym zjawiskiem niż zgon. Można je podzielić na poszczególne etapy: zapłodnienie, okres płodowy, poród... Śmierć to unicestwienie pozbawione etapów pośrednich. Żywa istota przestaje istnieć, znika, zostają tylko zwłoki. Byt pogrąża się w nicości, w niebycie - to największa ze wszystkich tajemnic. Wymyka się zdolności pojmowania, w tym sensie jest czymś całkowicie skandalicznym ${ }^{34}$.

Choć człowiek próbuje na różne sposoby oddalić śmierć, to jest ona czymś nieuchronnym: „człowiek to istota skazana na śmierć, od tego wyroku nie ma apelacji” ${ }^{35}$. Wielkie zadanie odraczania śmierci to domena medycyny, dlatego też chorobą chorób, chorobą a priori jest śmierć. Jak pisze Jankélévitch:

Człowiek jest istotą zagrożoną; przez każdą szczelinę ciała może doń wniknąć śmierć. Oto prawdziwe ryzyko. Ludzkie poczucie bezpieczeństwa jest siłą rzeczy nietrwałe ${ }^{36}$.

Śmierć jest tym, co nieuchronne. Jednak pomimo nieuchronności śmierci, człowiek nieustannie okłamuje siebie w tym zakresie. Zdaniem Jankélévitcha jest to swoisty wymóg egzystencjalny, gdyż bez tego życie stałoby się nieznośne. Człowiek radzi sobie ze śmiercią za pomocą myśli. Ale kiedy zaczyna snuć refleksje na temat śmierci, towarzyszy mu dziwne przekonanie, że jest niejako na zewnątrz tego zagadnienia, że śmierć dotyczy innych: „Śmierć odkładamy na później i odnosimy ją do innych za pomocą ustawicznego przesunięcia”37, i powtarza za J. Madaule’em: „wiem, że umrę, ale nie wierzę w to" ${ }^{38}$. Dzięki refleksji śmierć staje się zwyczajnym

$\begin{array}{ll}34 & \text { Tamże, s. } 33 . \\ 35 & \text { Tamże, s. } 22 . \\ 36 & \text { Tamże, s. } 25 . \\ 37 & \text { Tamże, s. } 26 . \\ 38 & \text { Tamże, s. } 27 .\end{array}$ 
problemem i traci swoją grozę. Dzięki myśli człowiek może wykraczać poza śmierć, problematyzując ją. Niestety, nigdy nie dokona tego w taki sposób, żeby śmierć została pokonana. Chodzi raczej o egzystencjalne poradzenie sobie ze świadomością śmierci. Jankélévitch przywołuje słynne rozróżnienie Gabriela Marcela na problem i tajemnicęe $e^{39}$. Problem jest przede mną, poza mną, jak przedmiot. Natomiast tajemnica nie jest czymś zewnętrznym, jestem w niej zanurzony. Śmierć może być potraktowana jako problem, ale nie przestaje być tajemnicą. Jak stwierdza francuski filozof:

Człowiek racjonalny, rozumny jest zarówno wewnątrz śmierci, jak i na zewnątrz niej $[\ldots]$. Człowiek może wykraczać poza śmierć, myśląc o niej. Jednocześnie znajduje się wewnątrz jej porządku. Wewnątrz i na zewnątrz. Tajemnicą nazywam tę część wewnętrzną, zanurzoną, mroczną ${ }^{40}$.

Śmierć jest zatem zarówno problemem, jak i tajemnicą, czymś logicznym i jednocześnie czymś niepojętym.

Śmierć jest zatem paradoksem, który dobrze widać w zetknięciu jej z myślą. Czy da się coś sensownego powiedzieć o śmierci? Przecież kiedy myślimy, śmierci nie ma, ona znika, a kiedy śmierć przychodzi, myśl nie ma nic do powiedzenia. To dlatego Jankélévitch stwierdza, że o śmierci lepiej wcale nie myśleć, bo „nie ma w niej nic, co dałoby się pomyśleć, nic, o czym dałoby się cokolwiek powiedzieć, śmierć szydzi sobie z myśli

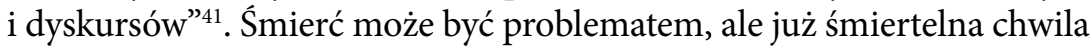
wymyka się konceptualizacji, ponieważ jest nicością.

Śmierć bawi się z naszą świadomością w chowanego: tam, gdzie jestem, śmierci nie ma, a kiedy śmierć tu jest, to ja już nie istnieję. Dopóki jestem, śmierć jest przyszłością; a kiedy śmierć się dopełnia, tu teraz nie ma już nikogo. Jedno z dwóch: świadomość albo śmiertelna obecność! ${ }^{42}$.

39 Por. G. Marcel, Być i mieć, tłum. P. Lubicz, Warszawa 1962, s. 118.

40 V. Jankélévitch, To, co nieuchronne, dz. cyt., s. 47.

41 Tamże, s. 86.

42 V. Jankélévitch, La mort, dz. cyt., s. 31, cyt. za: T. Gadacz, Historia filozofii XX wieku. Nurty, t. 1, dz. cyt., s. 534. 
Jeśli od powyższych analiz oddzielić pewien temperament egzystencjalistyczny Jankélévitcha, to pod jego wywodami mógłby się podpisać nawet marksista. Dla Engelsa przykładowo śmierć była ustaniem wymiany materii między ciałami białkowymi a otaczającą je przyrodą zewnętrzną i sprowadzała się zasadniczo do anihilacji bytowej człowieka. Jak miecz Damoklesa nad takimi poglądami wisi jedno przesłanie: dalej nic nie ma, nie ma żadnego ciągu dalszego. Śmierć jest brakiem przyszłości, dalszych losów, po niej istnieje jedynie bezpostaciowa wieczność nie-bycia. Tymczasem Jankélévitchowi chodzi o podkreślenie całkowitej odmienności życia od tego, co poza śmiercią. Jego zdaniem można mówić o jakimś innym porządku, niemającym nic wspólnego $\mathrm{z}$ naszą obecną egzystencją: „Śmierć to radykalna inność, bez jakiegokolwiek punktu odniesienia do naszego świata"43.

To dlatego dla Jankélévitcha ludzka egzystencja mimo śmierci nie jest absurdalna. Z tak pesymistycznego poglądu na śmierć wyłania się u niego całkiem optymistyczny obraz życia i wielka apoteoza ludzkiej godności. Jankélévitch wprowadził do swojej filozofii, pod wpływem Bergsona, kategorię organu-przeszkody. Jest on „przede wszystkim organem przeszkadzającym i utrudniającym: w ten sposób mózg jest organem-przeszkodą myślenia, oko jest organem-przeszkodą widzenia, język jest organem-przeszkodą sensu" ${ }^{\prime 4}$. Każdy organ człowieka jest swoistym paradoksem. Przykładowo oko pozwala widzieć, ale jednocześnie zawęża zakres postrzegania, bo mogę widzieć tylko coś określonego. Wyznacza ono pole widzenia, ale jednocześnie je zawęża. I tak samo zostaje potraktowana śmierć, jako organ-przeszkoda. Nie pozwala nam ona żyć, ogranicza życie, ale jednocześnie bez śmierci człowiek nie byłby człowiekiem:

Stała, choć utajona obecność śmierci uwzniośla życie, obdarza naszą egzystencję pasją, ferworem, energią. Można powiedzieć, że to, co nie umiera, nie żyje ${ }^{45}$.

43 Tenże, To, co nieuchronne, dz. cyt., s. 84.

${ }_{44}$ Tenże, La mort, dz. cyt., s. 89, cyt. za: T. Gadacz, Historia filozofii XX wieku. Nurty, t. 1, dz. cyt., s. 532 .

${ }_{45}$ V. Jankélévitch, To, co nieuchronne, dz. cyt., s. 19. 
Tak więc ostatecznie świadomość śmierci jest dla człowieka krzepiąca. Jest ona organem-przeszkodą: nadaje życiu sens, a jednocześnie pozbawia życie sensu.

Szala rozważań Jankélévitcha przechyla się w stronę życia, a nie zagłady. Jak powie: „uważam, że filozofia śmierci to w gruncie rzeczy refleksja o życiu" ${ }^{46}$. Jest to postawa cokolwiek zaskakująca. Mogłoby się wydawać, że skoro muszę umrzeć i czeka mnie nicość, to i moje życie jest pozbawione sensu. Jankélévitch patrzy na to odwrotnie: „Właśnie dlatego, że nie wiem, dokąd zmierzam, albo nawet wiem, że nie zmierzam donikąd, moje życie wydaje mi się nieskończenie cenne, cudowne, tajemnicze" ${ }^{37}$. Paradoksalnie brak sensu nadaje życiu sens. Przez śmierć życie uzyskuje swoje potwierdzenie. Śmierć czyni je możliwym. Naznacza naszą skończoność jako niepowtarzalną. Odbierając istnienie, jednocześnie nadaje mu formę i jakość. Gdyby nie możliwość śmierci, unieważnieniu uległyby pojęcia przygody i ryzyka. Jak powie Jankélévitch:

Mówimy „ryzyko” - doskonale, ale ryzyko czego? Jeśli mamy na myśli ryzyko wypadku, to przecież to ryzyko polega właśnie na tym, że wypadek może się okazać śmiertelny. Przestańmy owijać w bawełnę: ryzyko nazywa się śmierćt8.

Z jednej strony człowiek ma świadomość nieuchronności śmierci, z drugiej jednak nie zna jej daty. Tutaj Jankélévitch wykrywa mechanizm, dzięki któremu możliwa jest nadzieja. „Pomiędzy nieuchronnością wydarzenia a niepewnością terminu rozciąga się przestrzeń nieograniczonej nadziei" ${ }^{49}$. Jak mówiło stare porzekadło, póki życia, póty nadziei. Czym jest nadzieja? Dla francuskiego filozofa nadzieja jest ściśle związana $\mathrm{z}$ pojęciem bytu. Bytowanie dla niego to proces, $\mathrm{w}$ samym jego pojęciu zawiera się ciągłość. Ustanie bycia to czynnik pochodzący $\mathrm{z}$ zewnątrz. 
Śmierć jest zewnętrzna, transcendentna, niezależna od samego bytu. Byt nie zawiera w sobie własnej negacji. Negacja musi się pojawić z zewnątrz ${ }^{50}$.

Zatem śmierć mimo wszystko zaświadcza o nadziei ludzkiego życia.

\section{Jezusa „filozofia” śmierci}

Tischner w swoich rozważaniach na temat śmierci stoi całkowicie na stanowisku chrześcijańskim. To Jezus, założyciel chrześcijaństwa i jego centralna postać, który sam przeżył swoją śmierć, przynosi adekwatne wyjaśnienie problemu śmierci. Czy jednak można pytać o filozofię śmierci Jezusa, który nie był filozofem? Tischner poszukuje filozofii śmierci, jaką wyznawał Mistrz z Nazaretu, na tej podstawie, że przecież każdy człowiek ma jakąś ogólną koncepcję rzeczywistości i własnego w niej miejsca. Dodatkowo, kiedy odróżnimy filozofię czynu od czynu, jako wyrazu filozofii, to zobaczymy, że w przypadku Jezusa korelacja między czynem a myślą jest bardzo ścisła. Wskazuje na to logicznie uporządkowany czyn umierania i niemal zupełne milczenie na temat jego sensu i znaczenia. Stąd mówienie o filozofii śmierci Jezusa nie jest bezpodstawne, ale będzie to filozofia wyrażona przede wszystkim w czynie.

Tischnera interesuje szczególnie jeden moment. Pragnie on wydobyć tę koncepcję śmierci, jaką Jezus miał, decydując się na śmierć. Akt śmierci Jezusa ma bardzo szczególny charakter, choćby wymiar dobrowolnej ofiary. Nie byłby on możliwy w takim kształcie, gdyby Jezus uprzednio nie dysponował bardzo konkretną koncepcją śmierci. Jezusa filozofia śmierci musiała być więc taka, żeby mogła usprawiedliwić podjęty wybór. Naszym zadaniem będzie ukazanie momentów najbardziej charakterystycznych dla Jezusowej koncepcji śmierci, jakie wydobył Tischner, przyglądając się dziełu Jezusa. Pisze o niej tak: „Zjawia się ona jako intencjonalne założenie faktu śmierci Jezusa, stawiając nas tym samym w obliczu szczególnego przypadku filozofii 
śmierci samą śmiercią pisanej”⒈ Okazuje się zatem, że źródła chrześcijańskiej koncepcji śmierci tkwią nie tylko w słowach Jezusa, ale także, a może przede wszystkim, w Jego czynie. Tischner przywołuje słowa Alberta Camusa:

Chrystus przyszedł, aby rozwiązać dwa podstawowe problemy człowieka, śmierci i zła. Jego rozwiązanie polegało głównie na akcie podjęcia śmierci ${ }^{52}$.

To zdanie odsłania także głębokie pokłady wiary i nadziei, jakie żywili chrześcijanie od pierwszych wieków. Rozwiązanie problemu zła i śmierci dokonało się poprzez czyn, a nie poprzez nową teorię. To odróżnia Jezusa od filozofów. O ile ci ostatni potrafią co najwyżej objaśnić śmierć, o tyle Jezusowi chodziło o to, by ją zmienić. Jezus dokonuje również zmiany aksjologii śmierci. Pisze Tischner:

Jeżeli agonia staje się lekką, ponieważ została podjęta przez wieczną nadzieję, to znaczy, że dla tych, którzy wierzą, Jezus był wieczną nadzieją, agonia zmieniła swą wartość. Przewrót w naturze i w aksjologii śmierci stanowił immanentną część Jezusowego życiowego Czynu ${ }^{53}$.

A zatem Jezus dokonuje przewrotu w sferze wartościowania śmierci. Oznacza to jednak, że sam przeżywa śmierć jako wartość. Co takiego kryje w sobie śmierć, że Jezus widzi w niej wartość? Tischner śledzi

51 J. Tischner, Prolegomena..., dz. cyt., s. 249.

52 „Chrystus przyszedł, aby rozwiązać dwa podstawowe problemy człowieka, śmierci i zła. Jego rozwiązanie polegało głównie na akcie podjęcia śmierci. Bóg-Człowiek cierpi także, i to cierpliwie. Ani zło, ani śmierć nie mogą mu już być przypisywane, ponieważ sam został spotwarzony i uśmiercony. Noc Golgoty ma tylko dlatego znaczenie dla historii ludzkości, że w jej mrokach boskość, porzucając jaskrawo swe tradycyjne przywileje, przeżyła aż do końca rozpacz i trwogę śmierci. Tak wyjaśnia się lama sabactani i straszne zwątpienie Chrystusa będącego w agonii. Agonia stanie się lekką, skoro została podjęta przez wieczną nadzieję. Aby Bóg mógł być człowiekiem, potrzeba było, aby zwątpił” (A. Camus, Człowiek zbuntowany, tłum. J. Guze, Kraków 1993, s. 50). Por. I. Ziemiński, Metafizyka śmierci, dz. cyt., s. 271.

53 J. Tischner, Prolegomena..., dz. cyt., s. 265. 
śmierć Jezusa krok po kroku, chcąc wydobyć jej tajemnice, przesądzające o przeżywaniu śmierci jako wartości.

Pierwszym etapem, na którym śmierć objawia swoje tajemnice, jest sytuacja Jezusa w Ogrójcu. To tutaj staje On bezpośrednio wobec śmierci, która nadciąga jako aktywne pustoszenie. Ważnym elementem czasu Ogrójca jest ufna modlitwa Jezusa. Wprowadza ona klimat zaufania Bogu. Nic więc dziwnego, że patrzymy najczęściej na śmierć Jezusa jako na konsekwencję Jego posłuszeństwa. Tymczasem Tischner idzie za spostrzeżeniami Camusa i widzi w postawie Jezusa bardziej prowokację śmierci aniżeli posłuszeństwo ${ }^{54}$. Jezus wyraźnie prowokował śmierć już dużo wcześniej, przed Ogrójcem. Wystarczy wspomnieć Jego polemiki z faryzeuszami, wyzywające akty uzdrowień, wskrzeszeń, odpuszczenia grzechów. W Ogrójcu postawa prowokowania śmierci jakby na chwilę ustąpiła postawie posłuszeństwa, ale zaraz powraca, kiedy Jezus wychodzi naprzeciw swoich oprawców. To, co tutaj się ujawnia $z$ całą mocą, to prawda, że śmierć nie jest dla Jezusa ani przypadkiem, ani zaskoczeniem. Śmierć jest wartością i nie ma znaczenia, czy odsłoni ją akt prowokacji, czy posłuszeństwa.

Tischner polemizuje z Nietzschem. Niemiecki filozof również dostrzegł w postawie Jezusa prowokowanie śmierci, które nazywa „tęsknicą za śmiercią":

opadła Go tęsknica za śmiercią. Gdybyż On na pustyni pozostał z dala od dobrych i sprawiedliwych. Może by wówczas nauczył się żyć i ziemię kochać - i dar śmiechu poznałby aż nadto ${ }^{55}$.

Zdaniem Tischnera Nietzsche fałszywie odczytuje postawę Jezusa, gdyż nie dostrzega dwóch faktów. Po pierwsze, śmierć nie była dla Jezusa celem samym w sobie, ale rozwiązaniem problemu śmierci. Jednocześnie, choć Jezus przeżywał śmierć jako wartość, to jednak życie było dla Niego wartością podstawową:

54 Por. tamże, s. 267.

55 Tamże. 
Zauważmy bowiem, że nieustannie mówi On o życiu. Przyszedł życie dać, przyniósł z sobą napój życia, chleb życia, słowa życia, pokarm życia, wreszcie sam jest życiem ${ }^{56}$.

W dalszych analizach Tischner dochodzi do przekonania, że śmierć jawi się Jezusowi jako wartość ambiwalentna: pozytywna i negatywna zarazem. Jest wartością pozytywną, gdyż jest koniecznym pomostem do osiągnięcia życia. Jednocześnie śmierć jest wartością negatywną, gdyż wiążą się z nią wszystkie pustoszące procesy. Negatywność śmierci widać tė̇ w słowach Jezusa: „Niech odejdzie ten kielich” (por. Mt 26, 39). W tym właśnie punkcie Tischner zbliża się bardzo do Jankélévitcha koncepcji śmierci jako organu-przeszkody. Śmierć jest warunkiem życia. Jednakże w obu koncepcjach samo życie jest jeszcze odmiennie pojmowane: Tischnerowi chodzi o życie wieczne, pośmiertne, co jest nie do przyjęcia dla Jankélévitcha.

Czy Jezus nadaje swojej śmierci jakieś znaczenie? Czy Jego śmierć ma cechy śmierci heroicznej, męczeńskiej, śmierci odejścia czy śmierci sankcyjnej? Przeżywanie jej jako wartości pokazuje, że jest to zupełnie inna śmierć. Nie jest ona sensu stricto śmiercią heroiczną, gdyż śmierć heroiczna nie ma żadnej wartości pozytywnej. Bohater, podejmując heroiczny czyn, wie, że może umrzeć. Jezus tymczasem wiedział, że musi umrzeć. $Z$ tego powodu też w przypadku Jezusa nie można mówić o śmierci odejścia czy śmierci sankcyjnej. Być może jest to śmierć męczeńska, wszak Jezus został umęczony? Problem w tym, że Jezus nie traktował swojej śmierci jako świadectwa lub argumentu za czymś: „Jeżeli już cokolwiek miało być argumentem, to zmartwychwstanie, a nie śmierć" 57 .

Dochodzimy tutaj do odkrycia właściwego sensu i znaczenia śmierci Jezusa. Mistrz z Nazaretu wybiera śmierć, ponieważ w Jego świadomości śmierć sama w sobie ma sens zbawczy. Tischner tak tłumaczy tę soteryczną koncepcję śmierci: „Polega ona na tym, że śmierć jest 
pomostem przysposabiającym w sposób naturalny człowieka idącego po nim do nowego życia, że śmierć jest tamą kierującą spieniony nurt wody w określonym, z góry wybranym kierunku" ${ }^{58}$. Umieranie, według Jezusa, staje się widzialnym znakiem niewidzialnych narodzin.

Soteryczna koncepcja śmierci wyjaśnia nam całą postawę Jezusa, zwłaszcza Jego prowokowanie śmierci. Z czynu Jezusa wyczytujemy również chrześcijańską koncepcję śmierci. Jezus przyszedł po to, by rozwiązać problem zła i śmierci. Przyjmując śmierć, nadaje jej zupełnie nowe znaczenie. Odtąd śmierć może stać się drogą do życia i spełnieniem odwiecznych marzeń człowieka o nieśmiertelności.

\section{Nieśmiertelność czy miłość?}

Pragnienie nieśmiertelności towarzyszy człowiekowi od samego początku historii ludzkości ${ }^{59}$. Tischner mówił w jednym z kazań wielkanocnych:

Jak sięgnąć pamięcią, człowiek pragnął i marzył o tym, ażeby pokonać śmierć. Ale nie zawsze rozumiał, czym naprawdę jest śmierć. I dlatego jego marzenia kierowały go często na bezdroża ${ }^{60}$.

Sama idea nieśmiertelności była pojmowana w różny sposób. Alkmajon, jeden z pierwszych lekarzy greckich, zastanawiając się nad tajemnicą życia i śmierci, twierdził, że człowiek nie posiada mocy wiązania końca życia z jego początkiem. Tę umiejętność posiadają jedynie bogowie, których Grecy nazywali „nieśmiertelnymi”, a człowiek musi umrzećc $^{1}$. Z czasem jednak wypracowano sposoby radzenia sobie ze

58 Tamże, s. 269.

59 Por. A. Świeżyński, The Philosophy of Human Death. An Evolutionary Approach, Warszawa 2009, s. 61.

60 J. Tischner, Pokonać śmierć, [w:] tenże, Wiara ze słuchania. Kazania starosądeckie 1980-1992, Kraków 2009, s. 85.

${ }_{61}$ Por. tamże. Zob. także T. Gadacz, O umiejętności życia, dz. cyt., s. 68-69. Wprawdzie Laertios twierdzi, że Alkmajon wierzył, „że dusza jest nieśmiertelna i że jest w ciągłym ruchu, po- 
śmiercią, czego przykładem jest Sokrates. W obliczu wyroku skazującego go na śmierć, mówi:

Wy myślicie, że skazując mnie na śmierć, wyrządzacie mi jakąś krzywdę. Ale to nieprawda, to pozór, to iluzja. To dla was śmierć jest największą krzywdą, ale nie dla mnie, bo ja wiem, że we mnie mieszka nieśmiertelna dusza, która po śmierci ciała znajdzie swoje szczęście w niebie ${ }^{62}$.

Pojawia się zatem myśl o nieśmiertelnej duszy. Podobny pogląd miał Platon, który uznawał preegzystencję i nieśmiertelność ludzkiej duszy, ciało zaś jego zdaniem było skazane na śmierć. W czasach nowożytnych Spinoza dopuszczał nieosobową nieśmiertelność duszy, gdyż jego zdaniem, wszelkie indywidualne ludzkie "ja” pojawia się jako rezultat połączenia duszy z ciałem i dlatego po śmierci ciała podmiotowość musi zniknąć. Słychać w tym dalekie echo poglądów Arystotelesa, który uznawał ciało za zasadę jednostkującą byt ludzki. Filozofie witalistyczne głoszą podobne idee. Mówią one o tym, że człowiek umiera jedynie jako jednostka psychofizyczna, ale życie pojęte jako całość trwać będzie nadal. Dla Kanta nieśmiertelność duszy pojawia się jako postulat rozumu praktycznego i warunek sensowności zasady sprawiedliwości. Do tej plejady poglądów swoją kartę dopisuje także chrześcijaństwo. Dla Tischnera, który jest tutaj eksponentem koncepcji chrześcijańskiej, śmierć jest bramą prowadzącą do prawdziwego życia.

Dla Jankélévitcha nieśmiertelność, życie wieczne i temu podobne idee są naiwnymi mrzonkami. Świadczą one przede wszystkim o niepoważnym potraktowaniu samego problemu śmierci i zadowalaniu się tanią pociechą, której dostarczają wierzenia religijne. Pisze:

dobnie jak słońce" (Diogenes Laertios, Żywoty i poglądy słynnych filozofów, tłum. I. Krońska, Warszawa 1984, s. 509). O idei skończoności człowieka w myśli starożytnej zob. I. Ziemiński, Metafizyka śmierci, dz. cyt., s. 46.

62 J. Tischner, Pokonać śmierć, dz. cyt., s. 86. Por. Platon, Obrona Sokratesa, tłum. W. Witwicki, Warszawa 1982, s. 236. 
wielu wierzących wyobraża sobie zaświaty w sposób naiwny, traktuje śmierć jako rodzaj przetrwania, życie pozagrobowe to dla nich przedłużenie życia doczesnego, tyle, że bardziej komfortowe, łatwiejsze. Nie będzie już żadnych ograniczeń chorób, zapanuje wieczna szczęśliwość, nikt nie będzie umierać, ponieważ wszyscy będą już nieżywi. To niezbyt poważna, wręcz frywolna postawa ${ }^{63}$.

Zdaniem francuskiego filozofia, poważnie podchodzimy do śmierci, kiedy pozwalamy jej pozostawać tajemnicą. Śmierć ma w sobie coś apofatycznego: „Traktujemy śmierć z pełną powagą, jeśli mówimy: nie mam o niej pojęcia, nic o niej nie wiem, gdybym coś o niej wiedział, nie byłaby to już śmierć" 64 . Trudno sobie wyobrazić jakąkolwiek religię, która milczałaby na temat śmierci. Życie pozagrobowe i dalsze losy człowieka to ważne artykuły doktryn religijnych. Stąd wniosek Jankélévitcha, że jakiekolwiek poszukiwanie rozjaśnienia problemu śmierci $\mathrm{w}$ oparciu o wiarę i religię nie jest poważne, gdyż barwne niekiedy obrazy życia wiecznego, podsuwane przez rozum religijny, sprowadzają śmierć do zwykłego wydarzenia.

Wydawać by się więc mogło, że drogi Tischnera i Jankélévitcha radykalnie się rozchodzą, a ich poglądy są nie do pogodzenia. Obaj przez fakt śmierci chcą lepiej widzieć życie. Dla obu śmiertelność człowieka jest zaproszeniem, by otworzyć się jeszcze bardziej na życie. Różnią się jednak odpowiedzią, o jakie życie chodzi. Dla chrześcijańskiej koncepcji Tischnera celem jest życie wieczne, dla Jankélévitcha to życie, którym żyjemy obecnie, bo innego nie mamy. Obydwaj myśliciele są jak dwa wektory, które mają ten sam kierunek, ale różny zwrot. Jak powie francuski filozof:

Religia odgrywa w zagadnieniu śmierci wielką rolę, towarzyszy jej określone credo, wyobrażenia na temat Boga, zaświatów. Natomiast dla niewierzących ta postawa jest przede wszystkim postawą wobec życia, stawia nas bowiem wobec powagi istnienia ${ }^{65}$.

${ }_{63}$ V. Jankélévitch, To, co nieuchronne, dz. cyt., s. 41.
64 Tamże.
65 Tamże, s. 48. 
Jednakże nie jest tak do końca. Myśl Jankélévitcha ponownie zaskakuje, przybierając niespodziewany obrót. Francuski filozof bowiem nie usuwa pojęcia nieśmiertelności, ale inaczej to pojęcie rozumie: „Śmierć jest nieuchronna i nieodwracalna, ale też przypieczętowuje po wsze czasy czyjąś egzystencję, to, że ten ktoś był, fakt niezbywalny, nieusuwalny, niezniszczalny" ${ }^{16}$. Śmierć niesie zatem jakieś przesłanie, jakiś nieśmiertelny komunikat, w którym można przeczuć jakiś czynnik ponadnaturalny, pochodzący z innego porządku. Jankélévitch nie odrzuca zatem nieśmiertelności, lecz nie wierzy w istnienie argumentów, by jej dowieść, tak, jak nie wierzy w istnienie argumentów, by jej zaprzeczyć. Tutaj wyłania się wielka nadzieja. Tym, co może dać nadzieję poza śmierć, jest miłość.

Miłość jest tą, która mówi „tak”, a pierwszorzędnie tą, która odpowiada „nie" na „nie" śmierci, ponieważ odpowiada „tak” na „tak”, odpowiada afirmująco na afirmację i żywo na życie, jest echem pozytywności bycia [...]. Miłość jest obietnicą przyszłości ${ }^{67}$.

Powróćmy teraz do Tischnera. Dla niego rozwiązaniem śmierci jest zmartwychwstanie. Ale i tutaj pojawiają się zaskakujące interpretacje. Zmartwychwstanie nie dokonuje się $\mathrm{w}$ wyniku zajścia naturalnych przyczyn, ale jest łaską. Mówił o tym Tischner w jednym z kazań wielkanocnych, wygłoszonych w klasztorze klarysek w Starym Sączu:

Człowiek ma przyjąć zmartwychwstanie nie jako coś, co mu się ze sprawiedliwości należy, ale jako coś, co mu się należy przez łaskę. Oznacza to, że człowiek musi otworzyć się na zmartwychwstanie tak, jak się otwiera na łaskę ${ }^{68}$.

Kiedy człowiek otwiera się na łaskę zmartwychwstania? Co jest tą wewnętrzną siłą, decydującą o zmartwychwstaniu? Tischner odpowiada:

66 Tamże, s. 34.

67 V. Jankélévitch, La mort, dz. cyt., s. 430-431, cyt. za: T. Gadacz, Historia filozofii XX wieku. Nurty, t. 1, dz. cyt., s. 534.

68 J. Tischner, Pokonać śmierć, dz. cyt., s. 88. 
„Człowiek musi uwierzyć i musi umiłować. Zmartwychwstaje na tyle, na ile miłuje" ${ }^{\prime \prime}$. A zatem są siły w człowieku większe niż śmierć: wiara i miłość. Człowiek zmartwychwstaje, o ile miłuje:

Wszystko jest w człowieku skazane na śmierć: ciało i myśli, i wszystko. Jedynie jedna siła jest siłą większą niż śmierć. Jest to miłość człowieka. Bo dzięki miłości człowiek żyje i dzięki miłości człowiek zmartwychwstanie. To miłość jest tą mocą, która uczy człowieka, jak wiązać koniec życia z początkiem życia ${ }^{70}$.

Tischner następnie analizuje doświadczenie Jana Apostoła, o którym Tradycja Kościoła mówi, że był „umiłowanym uczniem” Jezusa. Dochodzi do wniosku, że te wszystkie doświadczenia zostawiły w nim głęboki ślad, a kiedy Apostoł był już sędziwym człowiekiem, mógł dokonać pewnej syntezy swoich doświadczeń. Dlatego zanotował w swoim liście krótkie zdanie: „Kto nie miłuje, trwa w śmierci” (por. 1 J 3, 14). Z przeżytych doświadczeń i z samodzielnych przemyśleń Jana zrodziła się ta zadziwiająco prosta mądrość:

u źródeł wszystkiego, u źródeł pustego grobu, tego, że to ten sam człowiek, i tego, że materia jest Mu posłuszna, leży miłość. Wszelkie życie rodzi się z miłości ${ }^{71}$.

Z miłości płynie życie, a z życia, jako największy i najcenniejszy owoc, bierze się miłość ${ }^{72}$.

Teraz widzimy, jak drogi Tischnera i Jankélévitcha się zbiegają. Miłość jest obietnicą przyszłości i nieśmiertelności. Ale też chrześcijańska

69 Tamże.

70 Tamże.

${ }^{71} \quad$ J. Tischner, Świat wielkiej nadziei, [w:] tenże, Miłość nas rozumie. Rok liturgiczny z księdzem Tischnerem, Kraków 2001, s. 103.

72 „Związek miłości i śmierci nie jest takim samym związkiem, jak na przykład związek życia i śmierci, gdzie śmierć stanowi naturalny kres życia [...]. Śmierć w odniesieniu do miłości nie oznacza także żadnego kresu, ale wręcz przeciwnie - pełnię. Śmierć nie przerywa miłości tak, jak przerywa życie” (T. Gadacz, O umiejętności życia, dz. cyt., s. 64). 
Między nieuchronną skończonością a nieśmiertelnością...

koncepcja zmartwychwstania nie jest żadnym pójściem na skróty. Człowiek jeśli zmartwychwstanie, to tylko dzięki miłości. Powie Jankélévitch: „Alternatywa przedstawia się następująco: albo żyć krótko, ale za to życiem prawdziwym, pełnym miłości, albo wieść egzystencję nieokreśloną, wyzbytą miłości, a więc w gruncie rzeczy nie żyć, doświadczać wiecznej śmierci"73. Być bez miłości to w ogóle nie być, i to jest najgłębsza prawda o śmierci, pod którą mogliby się podpisać i Tischner, i Jankélévitch. 